\title{
The Human Autoantibody Response to Apolipoprotein A-I Is Focused on the C- Terminal Helix: A New Rationale for Diagnosis and Treatment of Cardiovascular Disease?
}

\author{
Sabrina Pagano, ${ }^{1,2}$, Hubert Gaertner ${ }^{3 \odot}$, Fabrice Cerini ${ }^{3}$, Tiphaine Mannic ${ }^{1,2}$, \\ Nathalie Satta ${ }^{1,2}$, Priscila Camillo Teixeira ${ }^{4}$, Paul Cutler ${ }^{4}$, François Mach $^{5}$, \\ Nicolas Vuilleumier ${ }^{1,2 * \mp}$, Oliver Hartley ${ }^{3 * \ddagger}$ \\ 1 Department of Human Protein Sciences, Faculty of Medicine, University of Geneva, Geneva, Switzerland, \\ 2 Division of Laboratory Medicine, Department of Genetics and Laboratory Medicine, Geneva University \\ Hospitals, Geneva, Switzerland, 3 Department of Pathology and Immunology, Faculty of Medicine, \\ University of Geneva, Geneva, Switzerland, 4 Pharmaceutical Sciences, Pharma Research and Early \\ Development, F.Hoffmann-La Roche, Basel, Switzerland, 5 Division of Cardiology, Foundation for Medical \\ Researches, University of Geneva, Geneva, Switzerland \\ (- These authors contributed equally to this work. \\ $\ddagger$ These authors also contributed equally to this work. \\ * Oliver.Hartley@unige.ch (OH); Nicolas.Vuilleumier@ hcuge.ch (NV)
}

Citation: Pagano S, Gaertner H, Cerini F, Mannic T, Satta N, Teixeira PC, et al. (2015) The Human Autoantibody Response to Apolipoprotein A-I Is Focused on the C-Terminal Helix: A New Rationale for Diagnosis and Treatment of Cardiovascular Disease? PLOS ONE 10(7): e0132780. doi:10.1371/ journal.pone. 0132780

\section{Abstract}

Editor: Carmine Pizzi, University of Bologna, ITALY

Received: February 19, 2015

Accepted: June 19, 2015

Published: July 15, 2015

Copyright: $\odot 2015$ Pagano et al. This is an open access article distributed under the terms of the Creative Commons Attribution License, which permits unrestricted use, distribution, and reproduction in any medium, provided the original author and source are credited.

Data Availability Statement: All relevant data are within the paper.

Funding: This work was supported by Swiss National Science Foundation Grants \#310030_140736 to NV, by grants from the Leenaards Foundation no. 3698 to $\mathrm{NV}$ and $\mathrm{OH}$, and from the deReuters foundation no. 566 to NV. These funders had no role in study design, data collection and analysis, decision to publish, or preparation of the manuscript. F.Hoffmann-La Roche played an indirect role in the form of salaries for authors $\mathrm{PC}$ and PT, but did not have any additional role in the study

\section{Background}

Cardiovascular disease (CVD) is the leading cause of death worldwide and new approaches for both diagnosis and treatment are required. Autoantibodies directed against apolipoprotein $A-I(A p o A-I)$ represent promising biomarkers for use in risk stratification of CVD and may also play a direct role in pathogenesis.

\section{Methodology}

To characterize the anti-ApoA-I autoantibody response, we measured the immunoreactivity to engineered peptides corresponding to the different alpha-helical regions of ApoA-I, using plasma from acute chest pain cohort patients known to be positive for anti-ApoA-I autoantibodies.

\section{Principal Findings}

Our results indicate that the anti-ApoA-I autoantibody response is strongly biased towards the C-terminal alpha-helix of the protein, with an optimized mimetic peptide corresponding to this part of the protein recapitulating the diagnostic accuracy for an acute ischemic coronary etiology (non-ST segment elevation myocardial infarction and unstable angina) obtainable using intact endogenous ApoA-I in immunoassay. Furthermore, the optimized mimetic 
design, data collection and analysis, decision to publish, or preparation of the manuscript. The specific roles of these authors are articulated in the 'author contributions' section.

Competing Interests: I have read the journal's policy and the authors of this manuscript have the following competing interests: S. Pagano, H. Gaertner, P. Cutler, P.C. Teixeira, N. Vuilleumier and O. Hartley are named as inventors on a related patent application (Mimetic Peptides PCT/IB2013/), but have no other conflict of interest to disclose. This does not alter our adherence to PLOS ONE policies on sharing data and materials. peptide strongly inhibits the pathology-associated capacity of anti-ApoA-I antibodies to elicit proinflammatory cytokine release from cultured human macrophages.

\section{Conclusions}

In addition to providing a rationale for the development of new approaches for the diagnosis and therapy of CVD, our observations may contribute to the elucidation of how anti-ApoA-I autoantibodies are elicited in individuals without autoimmune disease.

\section{Introduction}

Despite increasing public awareness and major therapeutic progress, cardiovascular disease (CVD) remains the leading cause of morbidity and mortality worldwide [1]. Calls have been made to develop improved strategies for prevention, especially risk stratification $[1,2]$ and treatment [3] of both CVD and atherosclerosis, its underlying cause. Autoantibodies represent potentially useful biomarkers in risk stratification for atherosclerosis and CVD, some of them providing strong prognostic information independently of established risk factors [4].

Apolipoprotein A-I (ApoA-I), the major protein constituent of high density lipoprotein (HDL), is a $28 \mathrm{kDa}$ protein whose lipid-free structure consists of six alpha-helices arranged in two bundles, an N-terminal four-helix bundle and a C-terminal two-helix bundle [5, 6].

Although the respective contributions of the lipid versus the lipoprotein fraction towards the anti-atherogenic effects of HDL is still debated, several studies indicate that lipid-free ApoA-I itself can perform many of the atheroprotective activities ascribed to HDL, including reverse cholesterol efflux and inhibition of different pro-inflammatory, pro-oxidant and pro-thrombotic pathways $[7,8]$.

The link between anti-ApoA-I autoantibodies of immunoglobulin G (IgG) class and CVD was first noted in studies of patients with autoimmune diseases [9-13] and initially linked to a loss of atheroprotective HDL functions [9-11]. Subsequently, anti-ApoA-I IgG was shown (i) to be an independent predictor of poor cardiovascular outcome in several different populations at risk for CVD without concomitant autoimmune disease [14-17], and (ii) to provide incremental prognostic information over traditional risk factors for CVD [14-16, 18]. While the mechanism by which anti-ApoA-I autoantibodies are elicited is not currently understood, a series of cellular and animal studies have highlighted a causal role for anti-ApoA-IgG in atherogenesis, suggesting that it might represent a target for therapeutic intervention. Passive immunization of apoE ${ }^{-/-}$mice with anti-ApoA-I IgG was shown to increase both atherosclerotic lesion size as well as histological features of atherosclerotic plaque vulnerability [15]. Several different potential pathogenic mechanisms have been proposed [12, 15, 17, 19-21], including (i) induction of proinflammatory cytokine release from macrophages [12, $15,19]$ through interaction with the TLR2/CD14 complex [19], (ii) a pro-arrhythmogenic effect on cardiomyocytes in vitro $[17,20]$, and (iii) the induction of dysfunctional HDLs in vivo [21].

In this study we set out to characterize the anti-ApoA-I autoantibody response using a series of synthetic peptides derived from the different helical regions of the protein, with the aim of identifying candidate mimetic peptides suitable for use in diagnosis and/or therapy of atherosclerosis and CVD. 


\section{Materials and Methods Ethics Statement}

The research Ethics Committee of Geneva University Hospitals approved the study protocol. All patients gave written informed consent before enrolment.

\section{Clinical Study Design}

The clinical study presented here is ancillary to work derived from a previously published prospective single center study exploring the diagnostic accuracy of anti-ApoA-I IgG for type I NSTEMI diagnosis on 138 patients presenting to the emergency room for acute chest pain and meeting the required power of $90 \%$ [14]. As patients' plasma was no longer available for six patients, only 132 patients were available for analyses. To minimize the power impact of this sample shortage, we used a composite endpoint consisting of acute ischemic coronary etiology defined in the presence of type 1 NSTEMI $(n=22)$ or unstable angina $(n=7)$, according to the universal criteria of acute myocardial infarction AMI [14, 22]. The study endpoint was established by two independent senior cardiologists who were blinded to biochemical results. If patients did not fulfill the universal criteria of AMI in the presence of cTnI elevation, a nonischemic etiology was concluded only after exclusion of ischemia using myocardial scintigraphy or cardiac magnetic resonance imaging or after exclusion of a significant culprit coronary lesion by coronary angiography.

Inclusion criteria consisted of chest pain lasting more than $5 \mathrm{~min}$, regardless of age and gender, without ST-segment elevation on ECG defined by the absence of ST/T abnormalities or dynamic changes, such as non-persistent ST-segment elevation, ST depression, T-wave abnormalities or no ECG changes. Exclusion criteria consisted of STEMI, chest pain for a duration of less than $5 \mathrm{~min}$, prior hospitalization within 48 hours, known autoimmune diseases such as rheumatoid arthritis (RA), systemic lupus erythematosous (SLE) or anti-phospholipid syndrome (APS), known HIV or clinically patent signs of heart failure.

\section{Antibodies and patients plasma}

Goat polyclonal anti-human ApoA-1 IgG was obtained from Academy Bio-Medical Company. Patient plasma samples used in this study were archived from a previously published prospective single-centre study of 138 clinically well-characterized patients presenting at the emergency room for acute chest pain (ACP) [14], as described above. Blood was taken upon patient admission, centrifuged, aliquoted, and stored at $-80^{\circ} \mathrm{C}$ until analysis.

\section{Determination of human antibodies to ApoA-I and ApoA-I derived peptides by ELISA}

Anti-ApoA-I IgG autoantibodies in plasma were measured as described previously [12-18]. Briefly, Maxisorp plates (Nunc) were coated with purified and delipidated human ApoA-I, diluted in carbonate buffer $\mathrm{pH} 9.7(20 \mu \mathrm{g} / \mathrm{ml} ; 50 \mu \mathrm{l} /$ well $)$, for $1 \mathrm{~h}$ at $37^{\circ} \mathrm{C}$. The same procedure was used for the engineered peptides. After three washes with PBS/ 2\% (w/v) BSA (100 $\mu \mathrm{l} /$ well), all wells were blocked for $1 \mathrm{~h}$ with PBS/ $2 \%(\mathrm{w} / \mathrm{v}) \mathrm{BSA}$ at $37^{\circ} \mathrm{C}$. Samples were diluted 1:50 in PBS/ $2 \%(\mathrm{w} / \mathrm{v}) \mathrm{BSA}$ and incubated for $60 \mathrm{~min}$ at $37^{\circ} \mathrm{C}$. Samples at the same dilution were also added to a non-coated well to assess individual non-specific binding. After six further washes, $50 \mu \mathrm{l} /$ well of alkaline-phosphatase conjugated anti-(human IgG) (Sigma-Aldrich), diluted 1:1000 in PBS/ $2 \%(w / v) ~ B S A$, was incubated for $1 \mathrm{~h}$ at $37^{\circ} \mathrm{C}$. After six more washes (150 $\mu \mathrm{l} /$ well) with PBS/ $2 \%(\mathrm{w} / \mathrm{v}) \mathrm{BSA}$, the phosphatase substrate $p$-nitrophenyl phosphate $(50 \mu \mathrm{l} / \mathrm{well} ; 1 \mathrm{mg} / \mathrm{ml}$; Sigma-Aldrich) dissolved in $4.8 \%(\mathrm{w} / \mathrm{v})$ diethanolamine ( $\mathrm{pH} 9.8)$ was 
added. Each sample was tested in duplicate and $A 405 \mathrm{~nm}$ was determined after 20 min of incubation at $37^{\circ} \mathrm{C}$ (VERSAMax; MolecularDevices). The corresponding non-specific binding was subtracted from the mean absorbance for each sample. As in previous studies [12-18], positive immunoreactivity of human samples to ApoA-I was prospectively defined by an index $>37 \%$. This value was also used to define positive immunoreactivity to mimetic peptides, as defined upon receiver operating characteristic (ROC) curve analyses, and shown to provide an identical prevalence of positive immunoreactivity levels 11\% (15/132) to native ApoA-1 and 11\% (14/ 132) to F3L1 peptide (data not shown). Repeatability and reproducibility were determined at two levels. At a high level $(A 405 \mathrm{~nm}=1.2$, i.e. twice the cut-off value), the intra- and interassay coefficients of variation were $10 \%(n=10)$ and $17 \%(n=10)$ respectively. At the cut-off level, the intra- and inter-assay coefficients of variation were $16 \%(n=10)$ and $12 \%(n=8)$ respectively.

\section{Peptide synthesis}

Peptide fragments were synthesized according to a standard Fmoc-protocol on Rink amide AM resin (Novabiochem) using a Prelude synthesizer (Protein Technologies). For peptide F3L1, a pair of orthogonal protecting groups (allyl / allyloxycarbonyl) was used for the glutamic acid and lysine residues utilized to form the lactam bridge. At the end of resin elongation, these protecting groups were removed according to the procedure of Kates et al. [23]. On-resin lactam bridge formation [24], monitored by Kaiser ninhydrin test, was carried out with 3 equivalents of 6-chloro-benzotriazole-1-yl-oxy-tris-pyrrolidino-phosphonium hexafluorophosphate and 9 equivalents of $\mathrm{N}, \mathrm{N}$-diisopropylethylamine over $48 \mathrm{~h}$ at $37^{\circ} \mathrm{C}$. Peptides were cleaved from the resin with $90 \%$ trifluoroacetic acid, $5 \%$ phenol, $2.5 \%$ water and $2.5 \%$ triisopropylsilane, precipitated in diethylether, purified (to $>95 \%$ ) by reverse-phase HPLC, and lyophilized. The masses for each peptide were verified by mass spectrometry.

\section{CD spectroscopy}

Experiments were carried out in $0.1 \mathrm{~cm}$ quartz cell using a Jasco J-710 spectrometer with $100 \mu \mathrm{M}$ peptide solutions ( $1.25 \%$ trifluoroethanol in water) at $20^{\circ} \mathrm{C}$.

\section{Pro-inflammatory cytokine release}

Human monocytes were isolated from buffy coats from healthy donors at the Geneva University Hospitals Blood Transfusion Center and differentiated into macrophages by $24 \mathrm{~h}$ incubation with IFN- $\gamma(500 \mathrm{U} / \mathrm{ml})$ in complete RPMI-1640 culture medium ( $10 \%$ heat-inactivated FCS, $50 \mu \mathrm{g} / \mathrm{ml}$ streptomycin, $50 \mathrm{U} / \mathrm{ml}$ penicillin, $2 \mathrm{mM}$ L-glutamine), as previously described [19]. Assays of anti-ApoA-I IgG-mediated release of IL-6 and TNF- $\alpha$ from human monocytederived macrophages was carried out as described previously $[12,15,19]$ using a previously determined optimal concentration of polyclonal goat anti-ApoA-I IgG $(40 \mu \mathrm{g} / \mathrm{ml})$. Endotoxin contamination in the assay was excluded using the limulus amebocyte lysate Endochrome assay [19]. Where indicated, anti-ApoA-I IgG was pre-incubated with peptide F3L1 (1 mg/mL) for $2 \mathrm{~h}$ at room temperature prior addition to the cells. Each experiment was performed on cells from nine different healthy blood donors.

Raw cells were seeded in 96-well plates at $2 \times 10^{5}$ cells/well in DMEM culture medium (10\% heat-inactivated FCS, $50 \mu \mathrm{g} / \mathrm{ml}$ streptomycin, $50 \mathrm{U} / \mathrm{ml}$ penicillin) for $24 \mathrm{~h}$. Anti-Apo-A1 IgG $(100 \mu \mathrm{g} / \mathrm{ml})$ were incubated with peptides across a concentration range from $100 \mu \mathrm{g} / \mathrm{ml}$ to $0.06 \mu \mathrm{g} / \mathrm{ml}$ for $2 \mathrm{~h}$ at room temperature prior addition to cells. After $24 \mathrm{~h}$ stimulation, mouse TNF- $\alpha$ was quantified in the cell supernatants by ELISA according to manufacturer's instructions ( $R \& D$ system, $\mathrm{MN}$ ). 


\section{Statistical analyses}

Statistical analyses were performed using Statistica software (StatSoft). Association between high immunoreactivity levels and the study endpoint (acute ischemic coronary etiology) is presented as odds ratios (OR) with corresponding 95\% confidence intervals. Multivariable analyses using Logistic Regression were used to assess independency between variables. In this model, the endpoint was set as the dependent variable, and Thrombolyis in Myocardial Infarction (TIMI) score for NSTEMI [25] (allowing adjusting for major cardiovascular determinants of 14 days patient outcome within a single continuous variable) was set as the unique confounder due to the limited sample size. Receiver operating characteristic curve (ROC) analyses were performed using Analyse-It software for Excel (Microsoft). ROC curve comparison was performed using the Delong method [26]. Unless stated otherwise, results are expressed as median, interquartile range and range. Fisher's bilateral exact test, Mann-Whitney U-test and Spearman correlation were used when appropriate. $\mathrm{P}$ value $<0.05$ was considered as statistically significant.

\section{Results}

\section{Exploring the anti-ApoA-I autoantibody response}

In order to characterize the anti-ApoA-I autoantibody response, we chemically synthesized a panel of peptides corresponding to the different alpha-helical regions in the protein (Table 1). Each of the two longest helical regions, $\mathrm{C}$ and $\mathrm{D}$, were synthesized as two separate peptides $(\mathrm{C} 1, \mathrm{C} 2, \mathrm{D} 1, \mathrm{D} 2)$ whose sequences are located on either side of centrally located proline residues (Pro ${ }^{121}$ for Region C, Pro ${ }^{165}$ for Region D (Table 1)). The synthetic peptides were then used as coating antigens in a capture ELISA experiment to compare their immunoreactivity against pooled plasma from a subset of patients from our acute chest pain cohort [14] that had previously shown to be positive for anti-ApoA-I autoantibodies (Fig 1a).

We noted major differences in plasma immunoreactivity across the panel of peptides, with low signals obtained for Peptides A, C1, D1, D2 and E, intermediate signals for Peptides B and $\mathrm{C} 2$, and the strongest signal for Peptide F. Since these differences could have been due to differences in the capacities of the peptides to either (i) adsorb efficiently on assay plates or (ii) present authentic antigenic structures when adsorbed, we performed a second ELISA experiment

Table 1. ApoA-I-derived peptides used in this study. The alpha-helical regions in the lipid-free structure [5] of intact ApoA-I are indicated in italics. The centrally located proline residues in Regions $C$ and $D$ are indicated in bold.

\begin{tabular}{lll}
\hline \multicolumn{2}{c}{ Apo-AI (1-242) } & $\begin{array}{l}\text { DEPPQSPWDRVKDLATVYVDVKDSGRDYVSQFEGSALGKQLNLKLLDNWDSVTSTFSKLREQLGPVTQEFWDNLEKETE } \\
\text { GLRQEMSKDLEEVKAKVQPYLDDFQKKWQEEMELYRQKVEPLRAELQEGARQKLHELQEKLSPLGEEMRDRARAHVD } \\
\text { ALRTHLAPYSDELRQRLAARLEALKENGGARLAEYHAKATEHLSTLSEKAKPALEDLRQGLLPVLESFKVSFLSALEEYTKKLNT }\end{array}$ \\
Peptide & Residues & \\
\hline A & $10-39$ & RVKDLATVYVDVLKDSGRDYVSQFEGSALG \\
B & $50-84$ & WDSVTSTFSKLREQLGPVTQEFWDNLEKETEGLRQ \\
C1 & $97-120$ & VQPYLDDFQKKWQEEMELYRQKVE \\
C2 & $122-142$ & LRAELQEGARQKLHELQEKLS \\
D1 & $143-164$ & LGEEMRDRARAHVDALRTHLAPYSDEL \\
D2 & $166-187$ & YSDELRQRLAARLEALKENGGA \\
E & $190-213$ & ATEHLSTLSEKAKPALED \\
F & $220-242$ & GLLPVLESFKVSFLSALEEYTKKLNT \\
F & & KELYLLKFTVSKVGSTELPLNFSLA \\
(scrambled) & & \\
\hline
\end{tabular}




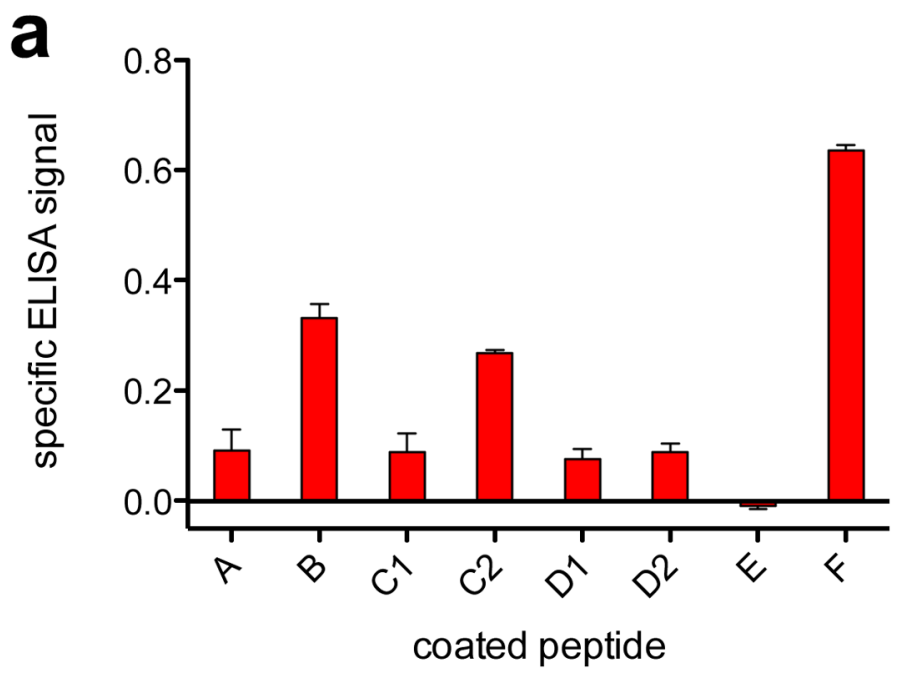

b

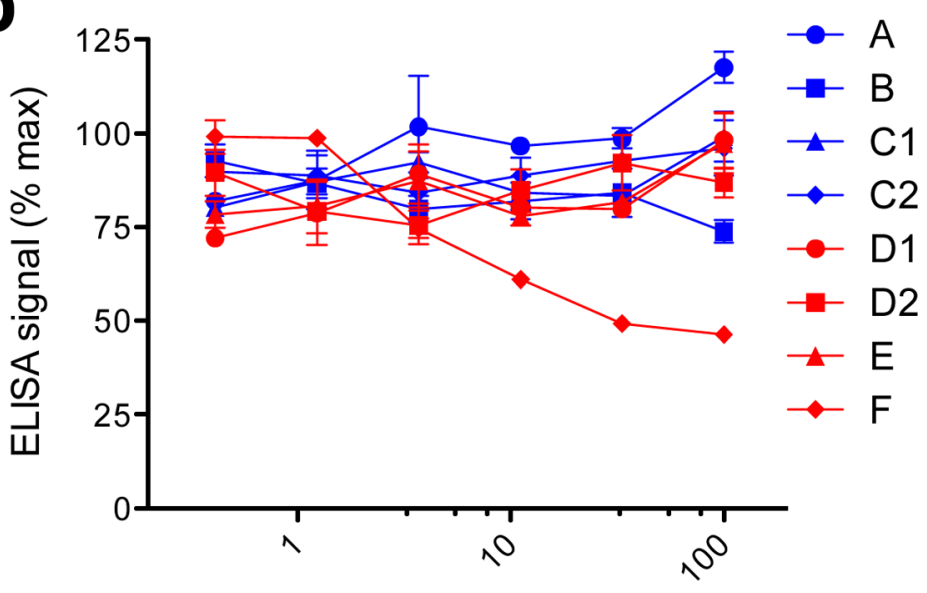

C

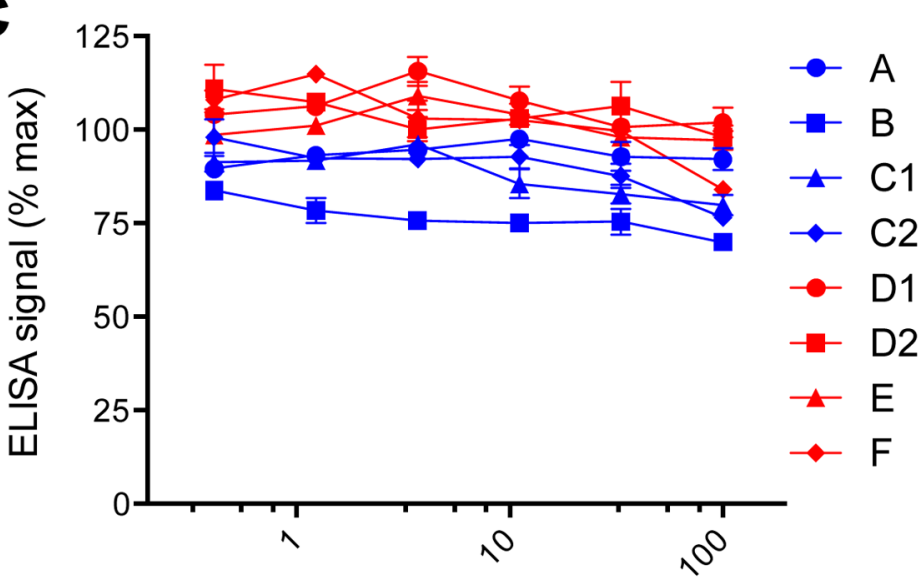

Peptide concentration $[\mu \mathrm{M}]$

Fig 1. The anti-ApoA-I autoantibody response is strongly biased towards the $C$-terminal alpha-helical region. ELISA experiments were carried out using a set of ApoA-I-derived peptides (Table 1). a. Capture ELISA assay to determine the immunoreactivity of plasma pooled from patients known to be positive for antiApoA-I autoantibodies against the set of peptides. Specific ELISA signals were calculated as [signal in well][mean background signal (uncoated well)]. Results are expressed as mean $\pm \operatorname{SD}(n=3) b$ and c. Competition ELISA to determine the capacity of the set of peptides to block binding of anti-ApoA-I antibodies from either 
pooled patient plasma (b) or goat polyclonal IgG (c) to immobilized ApoA-I. Plasma or antibody was preincubated ( $2 \mathrm{~h}$, room temperature) with peptides at the indicated concentrations prior to addition to assay wells. Percent maximal ELISA signals were calculated as $100 \times$ ([signal in well]-[mean background signal (uncoated well)])/([mean maximal signal (no peptide)]-[mean background signal]). Results are expressed as mean $\pm \operatorname{SD}(\mathrm{n}=3)$.

doi:10.1371/journal.pone.0132780.g001

in which the pooled patient plasma was pre-incubated with the different peptides in solution prior to addition to wells coated with intact ApoA-I (Fig 1b). Since none of the peptides cover more than $15 \%$ of the primary sequence of ApoA-I, we would not expect to observe more than $15 \%$ inhibition of ELISA signal generated by an unbiased polyclonal antibody response. Notably, Peptide F exhibited detectable dose dependent inhibition in this system, with inhibition at concentrations above $3 \mu \mathrm{M}$, reaching a maximal inhibition plateau of approximately $50 \%$ of the total anti-ApoA-I signal. In contrast, when pre-incubated with goat polyclonal antiApoA-I IgG, none of the peptides, including Peptide F, decreased signal inhibition by $15 \%$ at the highest concentration (Fig 1c). Our interpretation of this observation is that while the polyclonal antibody response generated in goats immunized with ApoA-I is unbiased towards any specific region of the protein, the autoantibody response in human subjects is biased towards the C-terminal region corresponding to Peptide F.

\section{'Stapling' Peptide F to increase alpha-helical content}

We next endeavored to optimize the mimetic qualities of Peptide F by stabilizing its native alpha-helical conformation using a 'helix-stapling' approach [24, 27]. We made use of glutamate and lysine residues present three positions apart (i.e. approximately one helix turn) in the sequence of Peptide $\mathrm{F}$ to form a lactam bridge. Circular dichroism (CD) spectroscopy analysis showed that the resulting peptide, F3L1 (Ac-GLLPVLESFKVSFLSALEEYTKKLNT-NH $\mathrm{H}_{2}$; lactam bridge residues underlined), indeed exhibited increased alpha-helical content compared to the parent molecule, Peptide F (Fig 2).

\section{Anti-ApoA-I immunoreactivity of human plasma samples can be blocked by engineered peptides}

We next performed ELISA assays using plasma samples from three different anti-ApoA-I autoantibody-positive patients from the cohort pre-incubated with Peptide F, a scrambled version of Peptide F (Table 1), or the stapled peptide F3L1 prior to addition to wells coated with ApoA-I (Fig 3). Peptide F3L1 showed consistently improved binding inhibition with respect to Peptide F. No inhibition was detectable using the scrambled version of Peptide F over the same concentration range.

\section{Immunoreactivity to Peptide F and F3L1 in human plasma for acute ischemic coronary event diagnosis}

To address the clinical relevance of these findings, we next tested whether immunoreactivity to F3L1 in patient serum or plasma could be used for prediction of acute ischemic coronary event diagnosis, as previously demonstrated for NSTEMI using immunoreactivity to full length deli-

pidated ApoA-I [14]. We used our standard in-house immunoassay [14] to assess the potential of Peptide F and F3L1 for use as capture antigens for NSTEMI prediction based on immunoreactivity with plasma samples from a cohort of 132 patients admitted to the emergency room with acute chest pain [14]. The baseline characteristics of these patients are summarized in Table 2. 


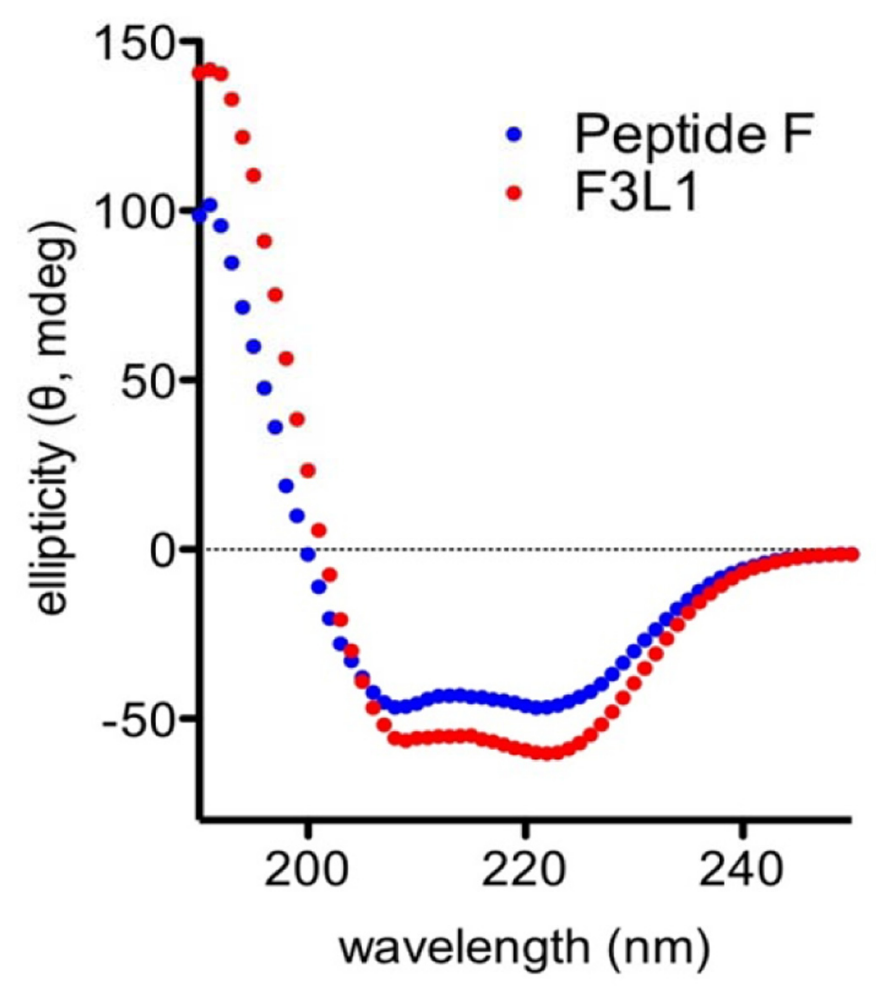

Fig 2. CD spectroscopy of peptide F3L1 indicates increased alpha-helical content. CD spectra of Peptide F and F3L1 were measured at $100 \mu \mathrm{M}$ concentration in water containing $1.25 \%$ trifluoroethanol. doi:10.1371/journal.pone.0132780.g002

Patients with high immunoreactivity to F3L1 were found to be more likely under aspirin treatment, to have a higher NSTEMI-TIMI score, and to have an acute ischemic coronary etiology upon discharge when compared to patients with low immunoreactivity to F3L1 (Table 2). As expected from the previous study [14], using intact ApoA-I as a coating antigen provided statistically significant prediction for an acute ischemic coronary event (area under curve (AUC) 0.75 ; $95 \%$ confidence interval (CI) $0.64-0.85 ; \mathrm{p}<0.0001$ ). While Peptide F did not provide statistically significant prediction of NSTEMI (AUC $0.55 ; 95 \%$ CI $0.41-0.68 ; \mathrm{p}=0.25$ ), peptide F3L1 provided results approaching those obtainable with the intact protein (AUC 0.64; 95\% CI 0.52-0.76; $\mathrm{p}<0.01$ ) (Fig 4), although the AUC difference between endogenous apoA-I and F3L1 was found to be statistically significant $(\mathrm{p}=0.03)$.

Translated into risk analyses, positive patient plasma immunoreactivity to $\mathrm{F} 3 \mathrm{~L} 1$ was associated with a 4-fold risk of an acute ischemic coronary event (univariate OR: 4.36, 95\% CI: 1.38$13.71, \mathrm{p}=0.01$ ), independently of the adjustment for the NSTEMI-TIMI score (OR: 3.61; 95\% CI: $1.01-13.00, p=0.04)$. In comparison, positive immunoreactivity to native ApoA-I increased the risk of an acute ischemic coronary event by 11 -fold (OR 10.88; 95\%CI: $2.64-$ $26.76, \mathrm{p}=0.004)$ and by 7 -fold (OR: 6.94, 95\%CI: 3.32-35.62, $\mathrm{p}<0.001)$ after the adjustment for the NSTEMI-TIMI score. Immunoreactivity to Peptide F was not statistically significantly associated with an increased risk of acute ischemic coronary event (data not shown).

Finally, Spearman correlation showed positive and significant associations between antibodies to F3L1 and CRP $(\mathrm{r}=0.23, \mathrm{p}=0.03)$, and the first cTnI value available upon patients' admission $(\mathrm{r}=0.18, \mathrm{p}=0.04)$. 

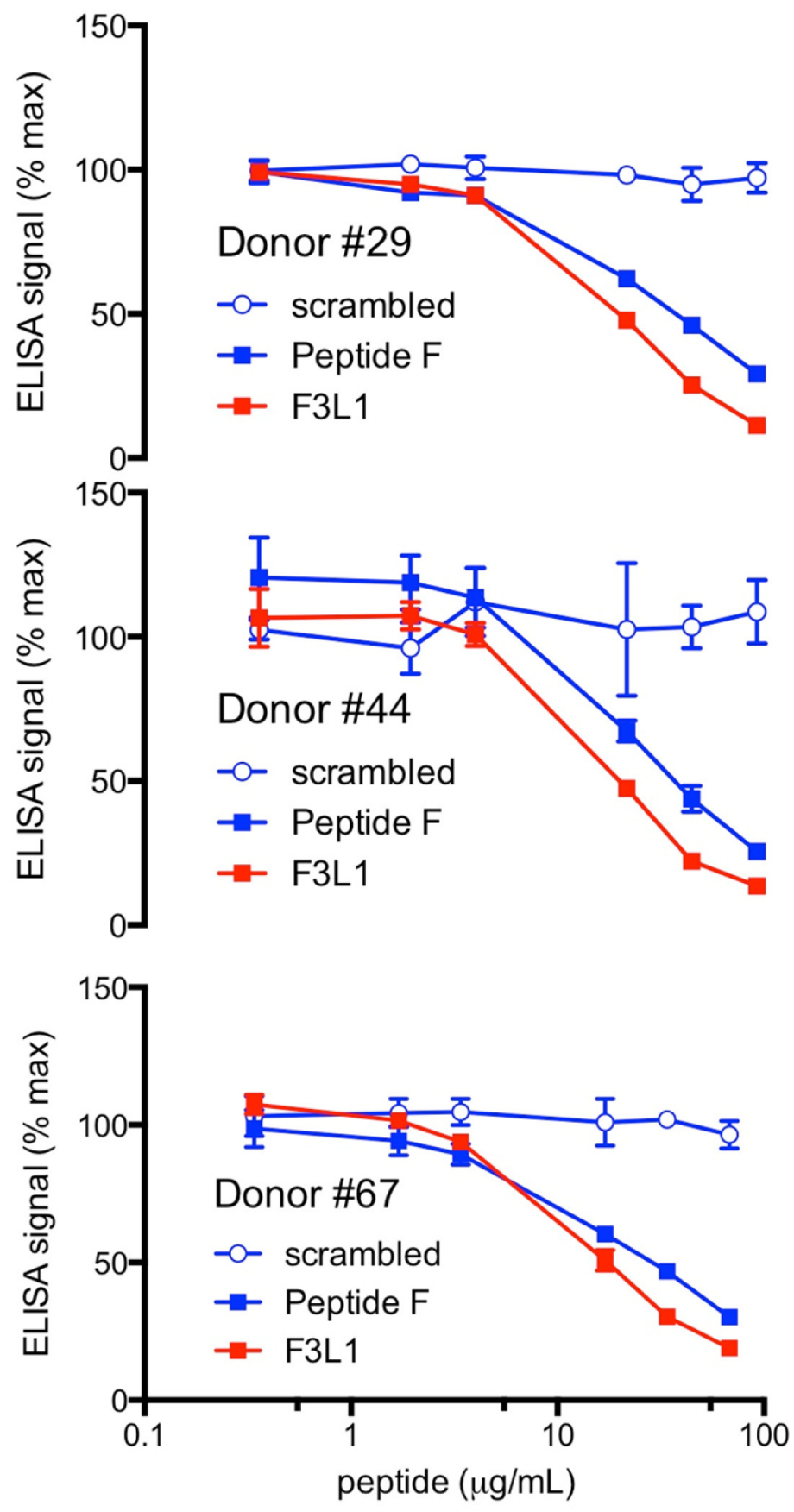

Fig 3. ApoA-I-derived peptides specifically inhibit binding of anti-ApoA-I IgG to immobilized ApoA-I. Competition ELISA to determine the capacity of peptides to block binding of anti-ApoA-I antibodies in plasma samples from three different patients known to be positive for anti-ApoA-I autoantibodies. Plasma samples were preincubated ( $2 \mathrm{~h}$, room temperature) with peptides at the indicated concentrations prior to addition to assay wells. Percent maximal ELISA signals were calculated as $100 \times$ ([signal in well]-[mean background signal (uncoated well)])/ ([mean maximal signal (no peptide)]-[mean background signal]). Results are expressed as mean $\pm \operatorname{SD}(n=3)$.

doi:10.1371/journal.pone.0132780.g003 
Table 2.

\begin{tabular}{|c|c|c|c|c|}
\hline & $\begin{array}{l}\text { Acute Chest Pain } \\
\text { Patients }(n=132)\end{array}$ & $\begin{array}{l}\text { High immunoreactivity to } \\
\text { F3L1 }(n=14)\end{array}$ & $\begin{array}{l}\text { Low immunoreactivity to F3L1 } \\
(n=118)\end{array}$ & $* \boldsymbol{P}$ \\
\hline Age in years, median (IQR) & $58(48-70 ; 23-93)$ & $62(54-68 ; 42-89)$ & $57.5(47-70 ; 23-93)$ & 0.54 \\
\hline \multicolumn{5}{|c|}{ Gender } \\
\hline Male, \% (n) & $63(83)$ & $71(10)$ & $62(73)$ & 0.56 \\
\hline Female, \% (n) & $37(49)$ & $29(4)$ & $38(45)$ & - \\
\hline \multicolumn{5}{|c|}{ Cardiovascular Risk factors } \\
\hline Diabetes, \% (n) & $18(24)$ & $29(4)$ & $17(20)$ & 0.49 \\
\hline Smoking, \% (n) & $23(31)$ & $7(1)$ & $25(30)$ & 0.26 \\
\hline Dyslipidemia, \% (n) & $36(48)$ & $43(6)$ & $36(42)$ & 0.63 \\
\hline Obesity, \% (n) & $14(19)$ & $7(1)$ & $15(18)$ & 0.71 \\
\hline Hypertension, \% (n) & $43(58)$ & $57(8)$ & $42(50)$ & 0.38 \\
\hline Known CHD, \% (n) & $28(37)$ & $36(5)$ & $27(32)$ & 0.61 \\
\hline Known Stroke, \% (n) & $5(6)$ & $7(1)$ & $4(5)$ & 0.86 \\
\hline Positive Familial History, \% (n) & $11(15)$ & $7(1)$ & $12(14)$ & 0.77 \\
\hline Systolic blood pressure, $\mathrm{mmHg}$ & $130(120-150 ; 95-200)$ & $130(120-154 ; 90-164)$ & $135(120-148 ; 97-200)$ & 0.69 \\
\hline Diastolic blood pressure, $\mathrm{mmHg}$ & $75.5(90-70 ; 50-110)$ & $79.5(70-80 ; 70-90)$ & 75 (70-90;50-110) & 0.66 \\
\hline Heart Rate, bpm & $74.5(65-83 ; 40-170)$ & $72.5(64-78.5 ; 47-97)$ & $74.5(65.5-84 ; 40-170)$ & 0.56 \\
\hline Body Mass Index, $\mathrm{kg} / \mathrm{m}^{2}$ & $\begin{array}{l}26.1(23.9-29.4 ; 16.4- \\
38.3)\end{array}$ & $26.7(23.6-29.4 ; 21.9-32.3)$ & $26.0(23.9-29.4 ; 16.4-38.3)$ & 1 \\
\hline NSTEMI-TIMI score at admission & $2(1-3 ; 1-6)$ & $3(2-4 ; 1-5)$ & $2(1-3 ; 1-6)$ & 0.03 \\
\hline \multicolumn{5}{|c|}{ Medical Treatment Upon Admission } \\
\hline Aspirin, \% (n) & $39(52)$ & $71(10)$ & $36(42)$ & 0.01 \\
\hline Clopidogrel, \% (n) & $8(11)$ & $7(1)$ & $8(10)$ & 0.95 \\
\hline$\beta$-blockers, \% (n) & $28(37)$ & $43(6)$ & $26(31)$ & 0.27 \\
\hline ACE inhibitors, \% (n) & $24(32)$ & $36(5)$ & $23(27)$ & 0.38 \\
\hline AT-1 blockers, \% (n) & $9(12)$ & $14(2)$ & $8(10)$ & 0.7 \\
\hline Insulin, \% (n) & $5(7)$ & $0(0)$ & $6(7)$ & 0.72 \\
\hline Oral anti-diabetic agents, \% (n) & $20(26)$ & $29(4)$ & $17(22)$ & 0.5 \\
\hline Diuretics, \% (n) & $17(23)$ & $29(4)$ & $16(19)$ & 0.41 \\
\hline Calcium Channel Blockers, \% (n) & $11(14)$ & $7(1)$ & $11(13)$ & 0.82 \\
\hline Statins, \% (n) & $32(42)$ & $50(7)$ & $30(35)$ & 0.1 \\
\hline \multicolumn{5}{|c|}{ Biological Parameters Upon Admission } \\
\hline Total Cholesterol, mmol/l & $4.4(3.9-5 ; 2.7-6.7)$ & $4.2(3.5-4.4 ; 3-5.2)$ & $4.5(4-5 ; 2.7-6.7)$ & 0.33 \\
\hline $\mathrm{HDL}, \mathrm{mmol} / \mathrm{l}$ & $\begin{array}{l}1.05(0.79-1.28 ; 0.65- \\
2.29)\end{array}$ & $0.88(0.77-1.53 ; 0.7-1.65)$ & $1.09(0.91-1.28 ; 0.65-2.29)$ & 0.65 \\
\hline LDL, mmol/l & $2.58(2.1-3.15 ; 0.71-4.56)$ & $2.81(1.59-3.03 ; 1.21-14.6)$ & $2.57(2.10-3.15 ; 0.71-4.56)$ & 0.79 \\
\hline Triglycerides, mmol/l & $1.41(0.89-2.14 ; 0.3-5.1)$ & $1.31(0.84-1.53 ; 0.3-2.38)$ & $1.48(0.96-2.14 ; 0.44-5.09)$ & 0.4 \\
\hline Creatinine, $\mu \mathrm{mol} / \mathrm{L}$ & $78.5(67-89 ; 45-131)$ & $97(62-127 ; 51-196)$ & $77.5(65.5-88.5 ; 39-285)$ & 0.92 \\
\hline GFR, $\mathrm{mL} / \mathrm{min}$ & $70(60-110 ; 14-202)$ & $60(52-91.5 ; 29-167)$ & $72(60-111 ; 14-202)$ & 0.28 \\
\hline CRP, mg/L & $3(1-10 ; 0-274)$ & $5.5(3-10 ; 1-23)$ & $3(1-10 ; 0-274)$ & 0.21 \\
\hline Initial cTnl value, $\mathrm{ng} / \mathrm{ml}$ & $0.02(0.01-0.04 ; 0-23)$ & $0.05(0.01-0.13 ; 0.005-3.5)$ & $0.02(0.01-0.036 ; 0-23)$ & 0.08 \\
\hline \multicolumn{5}{|c|}{ Diagnostic at Discharge, \% (n) } \\
\hline Acute Ischemic Coronary event (NSTEMI/UA) & $22(29)$ & $50(7)$ & $19(22)$ & 0.002 \\
\hline Non Ischemic Etiology: & $78(103)$ & $50(7)$ & $93(110)$ & - \\
\hline Parietal etiology & $7(9)$ & $7(1)$ & -8 & - \\
\hline Gastroenterological etiology & $5(7)$ & $14(2)$ & -5 & - \\
\hline Pulmonary etiology & $2(3)$ & 0 & -3 & - \\
\hline
\end{tabular}


Table 2. (Continued)

\begin{tabular}{|c|c|c|c|c|}
\hline & $\begin{array}{l}\text { Acute Chest Pain } \\
\text { Patients }(n=132)\end{array}$ & $\begin{array}{l}\text { High immunoreactivity to } \\
\text { F3L1 }(n=14)\end{array}$ & $\begin{array}{l}\text { Low immunoreactivity to F3L1 } \\
(n=118)\end{array}$ & ${ }^{*} \boldsymbol{P}$ \\
\hline Supraventricular Arrhythmia & $3(4)$ & $0(0)$ & -4 & - \\
\hline Pulmonary embolism & $2(3)$ & $7(1)$ & -2 & - \\
\hline Pericarditis & $2(2)$ & $0(0)$ & -2 & - \\
\hline Psychogenic & $2(3)$ & $0(0)$ & -3 & - \\
\hline Malignant hypertension & $1 / 1)$ & $0(0)$ & -1 & - \\
\hline $\begin{array}{l}\text { Unknown, but pulmonary embolism and aortic } \\
\text { dissection ruled-out }\end{array}$ & $59(78)$ & $21(3)$ & $60(75)$ & - \\
\hline
\end{tabular}

*P value was computed by comparing patients with high vs low anti-F3L1 immunoreactivity. CHD: coronary heart disease, bpm: beats per minute, GFR: glomerular filtration rate.

doi:10.1371/journal.pone.0132780.t002

\section{ApoA-I-derived peptides block anti-ApoA-I IgG-mediated proinflammatory cytokine release}

Both plasma from human myocardial infarction patients known to be positive for anti-ApoA-I autoantibodies and anti-ApoA-IgG from immunized animals have been shown to elicit a dosedependent release of proinflammatory cytokines from human primary macrophages with an optimal response at $40 \mu \mathrm{g} / \mathrm{ml}[12,15,19]$. We next used a Luminex assay to measure the capacity of peptide F3L1 to inhibit endotoxin-free anti-ApoA-I IgG-mediated proinflammatory cytokine release in human monocyte-derived macrophages (Fig $5 \mathrm{a}$ and $5 \mathrm{~b}$ ). As expected from previously published work $[12,15,19]$, anti-ApoA-I IgG elicited a significant increase in production of both in IL- 6 and TNF- $\alpha$ when compared to control IgG (Ctl IgG; $p<0.0001$ for both

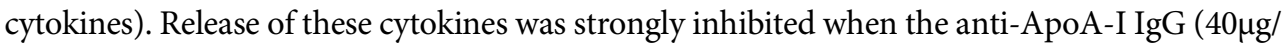
$\mathrm{ml})$ was pre-incubated with peptide $\mathrm{F} 3 \mathrm{~L} 1(1 \mathrm{mg} / \mathrm{mL}, 342 \mu \mathrm{M})$ prior to addition to cells, decreasing the median IL-6 production from 250.9 to $19.2 \mathrm{pg} / \mathrm{ml}(\mathrm{p}=0.008)$, and the median TNF- $\alpha$ production from 183.7 to $48.4 \mathrm{pg} / \mathrm{ml}(\mathrm{p}=0.028)$. On the other hand, co-incubating anti-ApoA-I

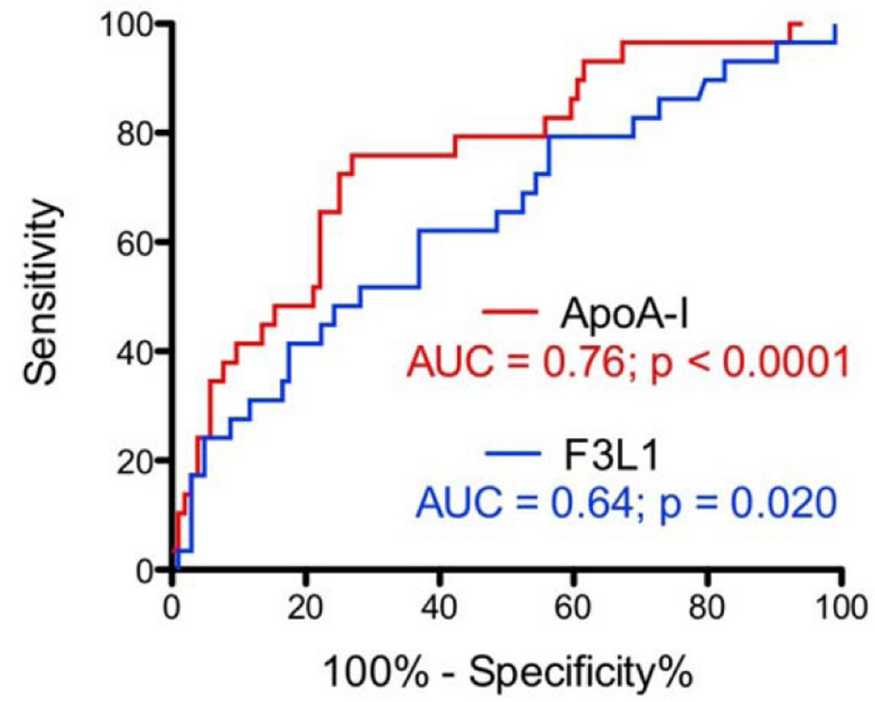

Fig 4. Predicitve accuracy for acute ischemic coronary events of immunoreactivity to F3L1 and to native ApoA-I.

doi:10.1371/journal.pone.0132780.g004 
a

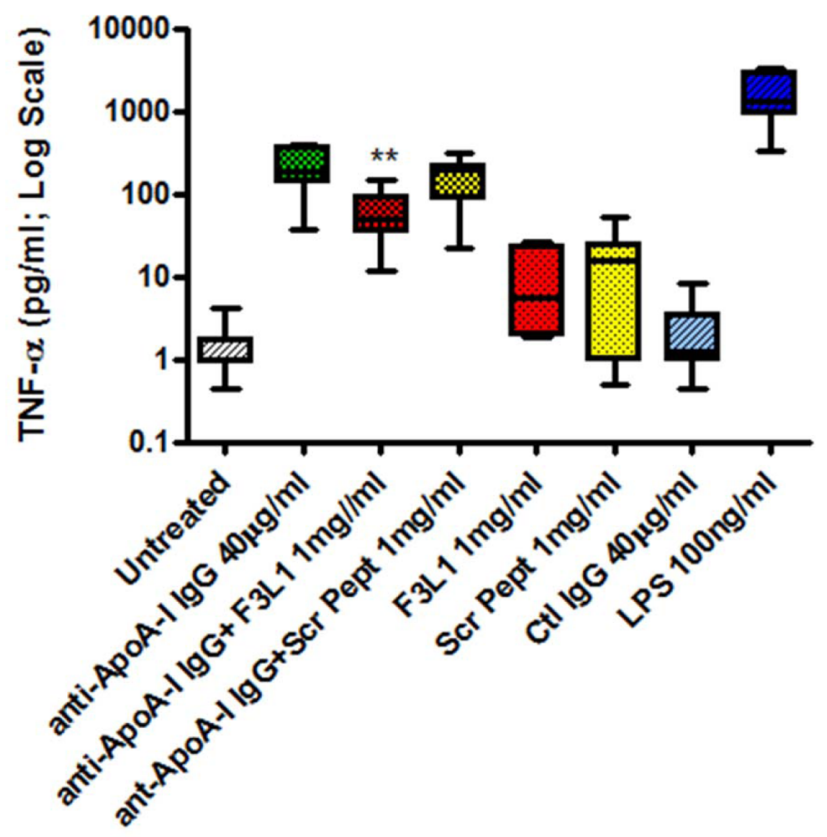

b

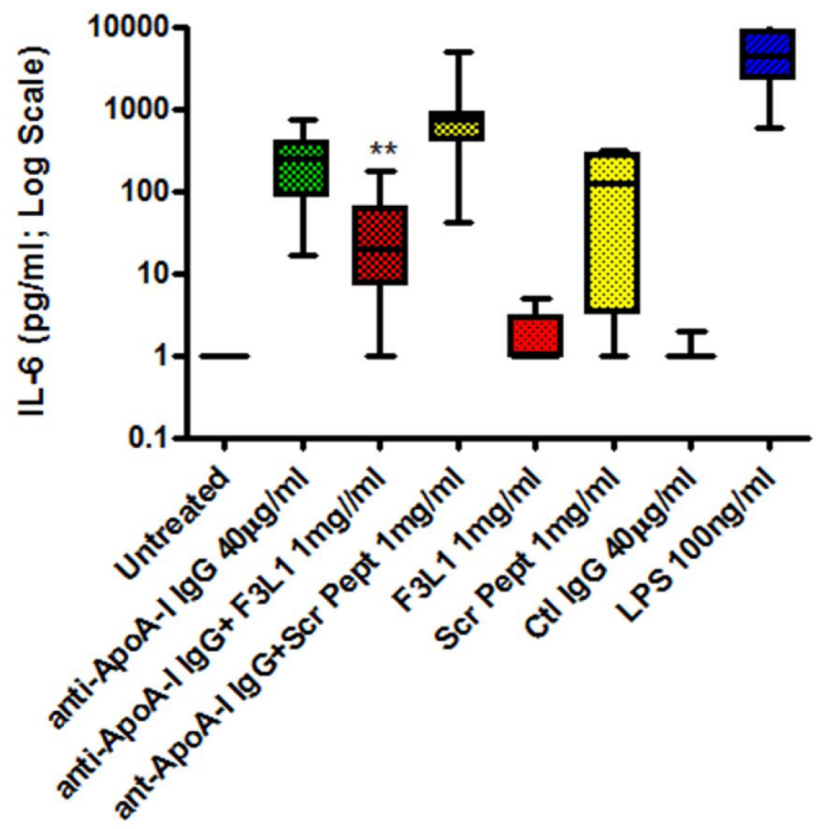

Fig 5. Peptide F3L1 inhibits anti-ApoA-I IgG-mediated release of proinflammatory cytokines from cultured human monocyte-derived macrophages. Release of proinflammatory cytokines TNF- $\alpha$ (a) IL-6 (b) from human monocyte-derived macrophages induced by endotoxin-free goat polyclonal anti-ApoA-I IgG was determined with or without preincubation (2 $\mathrm{h}$ at room temperature) of the anti-ApoA-I lgG with peptide F3L1 (1 mg/mL) and the corresponding scrambled peptide (Scr Pept). Experiments were repeated using cells from nine different healthy donors, with results expressed as median, interquartile range $(\mathrm{IQR})$ and range. ${ }^{* *} \mathrm{p}$ value $<0.008$.

IgG with the corresponding scrambled peptide did not inhibit the pro-inflammatory response induced by the anti-ApoA-I antibodies. When compared to control IgG, F3L1 was devoid of significant biological activity in terms of cytokine production, although a trend was observed for TNF- $\alpha$ production ( $\mathrm{p}=0.05$; Fig $5 \mathrm{a}$ and $5 \mathrm{~b}$ ). We were unable to measure the inhibitory activity of intact purified and delipidated ApoA-I in this assay because traces of endotoxin elicit significant levels of background cytokine secretion (NV and SP, unpublished observations).

As shown in Fig 6a and 6b, anti-ApoA-I IgG-induced TNF- $\alpha$ and IL-6 release in human monocyte-derived macrophages was inhibited by F3L1 in a dose-dependent manner. When used at the highest concentration $(1 \mathrm{mg} / \mathrm{mL})$ in this model, Peptide F provides a level of inhibition of anti-ApoA-I IgG-mediated cytokine release comparable to that of F3L1. To compare the potency of the stapled versus the unstapled peptide, we performed dose-response experiments for inhibition of anti-ApoA-I IgG-mediated cytokine release in the RAW mouse macrophage cell line (Fig 7). In this system, F3L1 is clearly a more potent inhibitor than Peptide F, with the scrambled peptide showing no detectable inhibitory activity.

\section{Discussion}

\section{Strong bias in the human anti-ApoA-I IgG autoantibody response towards the C-terminal alpha-helix}

Our results indicate that the anti-ApoA-I IgG autoantibody response is strongly biased towards the C-terminal alpha-helix (Fig 1a and 1b). These findings, obtained with pooled patient 


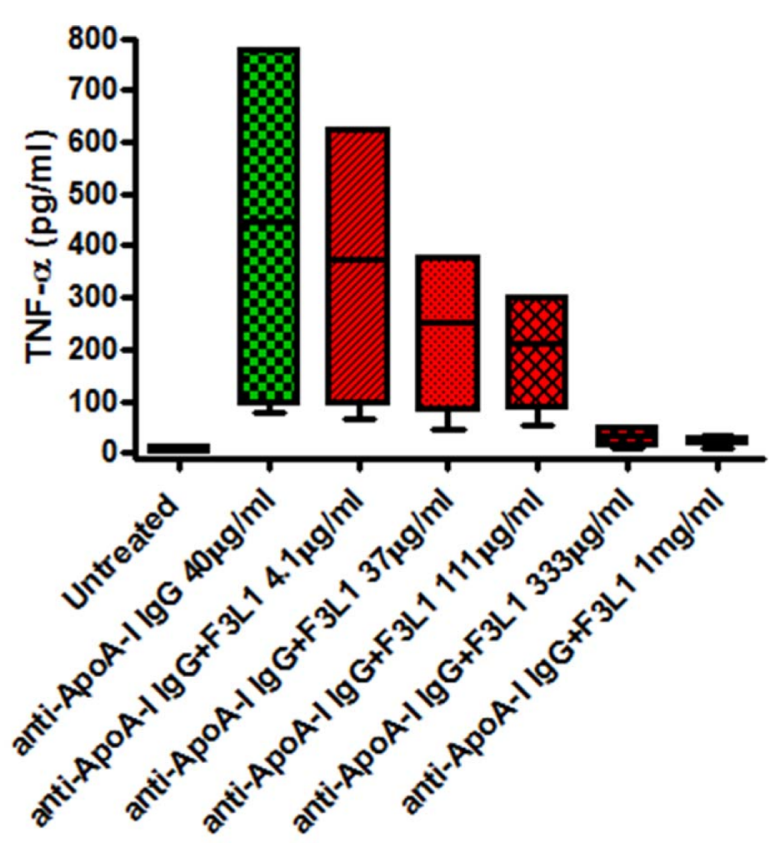

b

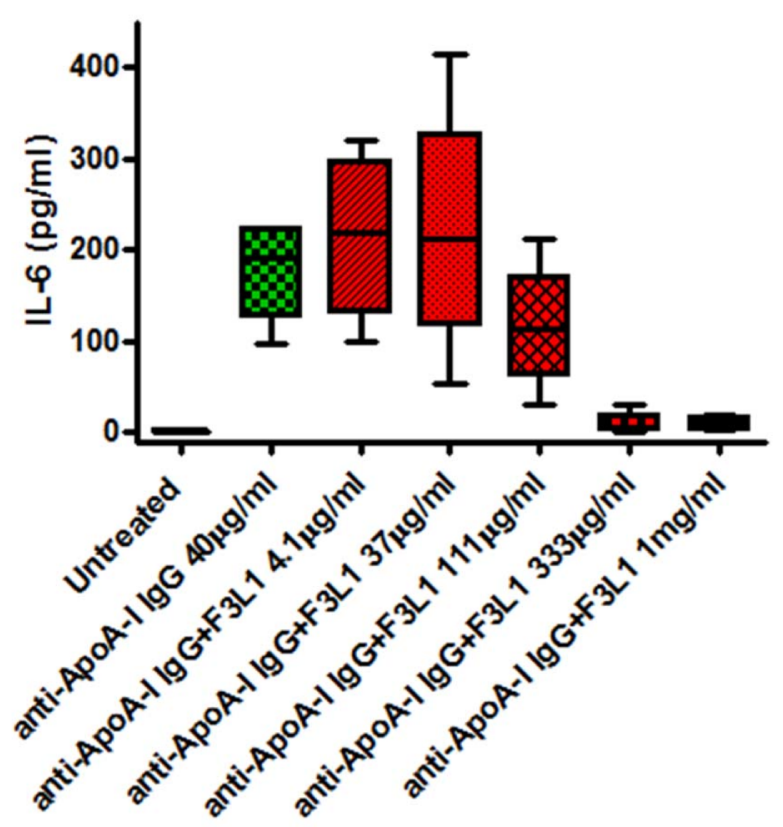

Fig 6. Peptide F3L1 dose-dependently inhibits anti-ApoA-I IgG-induced TNF- $\alpha$ and IL-6 production. Anti-ApoA-I IgG was incubated with the indicated F3L1 concentrations (preincubation $2 \mathrm{~h}$ at room temperature) prior to addition to cultured human monocyte-derived macrophages. Levels of proinflammatory cytokines were determined after $24 \mathrm{~h}$ culture. Experiments were repeated using cells from three different healthy donors, with results expressed as median, interquartile range (IQR) and range. Kruskal-Wallis test for a trend showed $p$ value $=0.01$ for TNF- $\alpha$, and $p$ value $=0.005$ for IL-6.

doi:10.1371/journal.pone.0132780.g006

plasma, were recapitulated in plasma samples obtained from three different individual patients, where an optimized ApoA-I mimetic peptide corresponding to amino acids 240-267 (i.e. covering less than $11 \%$ of the total linear sequence of the protein) was capable of neutralizing up to $90 \%$ of the total anti-ApoA-I IgG signal (Fig 3). Our observations confirm and extend findings obtained in a previous study in which peptide fragments were obtained by proteolytic digestion of purified endogenous ApoA-I [28]. While in this previous study immunoreactivity was noted to a long peptide fragment corresponding to residues 141-182 of ApoA-I, we did not detect binding to two shorter peptides that partially cover this region, Peptide D1 (143-164) and Peptide D2 (166-187). The simplest explanation for this finding is the anti-ApoA-I autoantibodies that bind to the longer peptide recognize an epitope that is not entirely present in either of the two shorter peptides. Together, these studies provide compelling support for the idea that the anti-ApoA-I IgG autoantibody response is strongly focused towards an epitope on ApoA-I corresponding to the C-terminal alpha-helix, but in order to robustly test this hypothesis it would be necessary to screen a larger number of individual patient samples.

\section{Characteristics of the C-terminal alpha-helix epitope of ApoA-I}

Although the peptides used in this study were designed based on the structure of lipid-free ApoA-I, it is likely that the epitope or epitopes present on Peptide F that are engaged by antiApoA-I antibodies are also present and available for interaction on lipid-associated ApoA-I. According to structural studies of lipid-associated and lipid-free ApoA-I (reviewed in [6]), the region corresponding to Peptide F is always present in an alpha-helical conformation, with its 


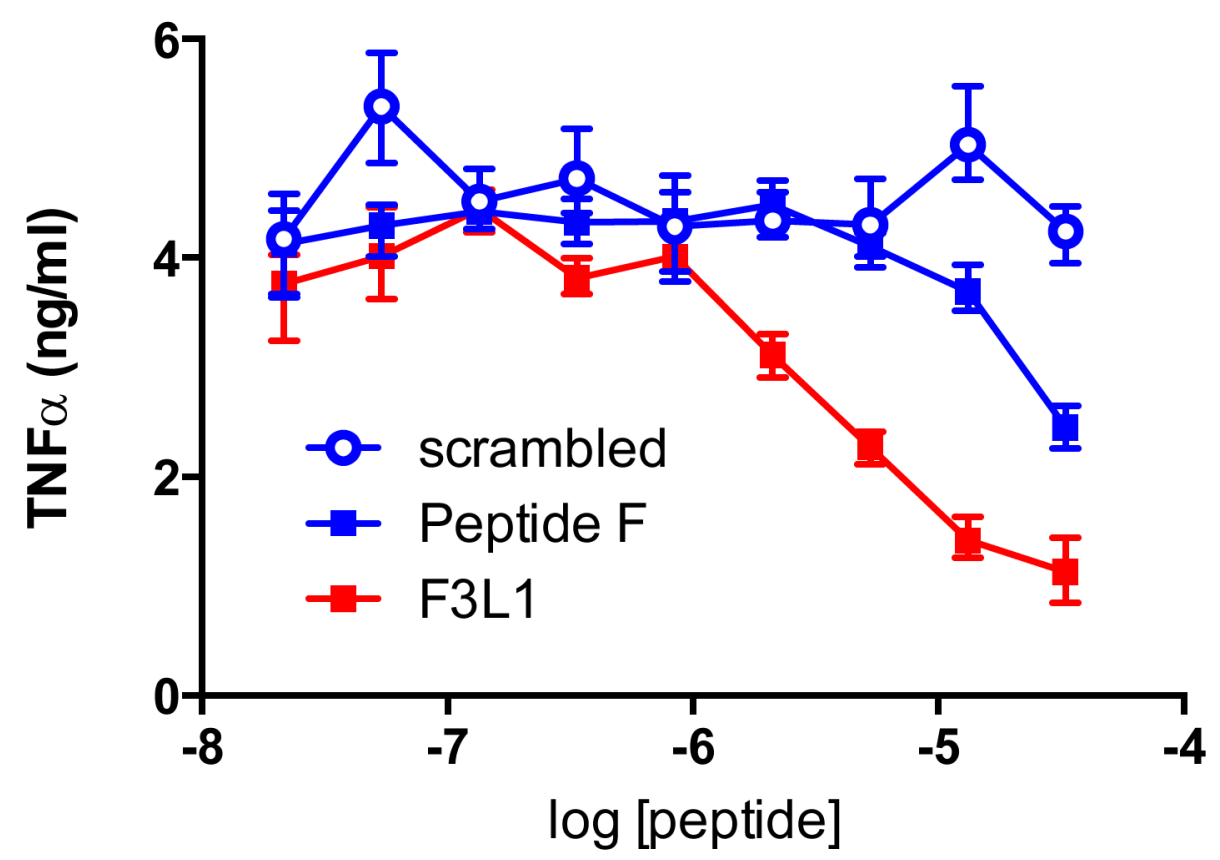

Fig 7. Comparing the inhibitory potency of Peptide F and F3L1 on anti-ApoA-I IgG-induced TNF- $\alpha$. Anti-ApoA-I IgG was incubated with the indicated peptide concentrations (preincubation $2 \mathrm{~h}$ at room temperature) prior to addition to cultured RAW cells. Levels of proinflammatory cytokines (TNF- $\alpha$ ) were determined after $24 \mathrm{~h}$ culture. Mean levels $(n=3)$ are shown with error bars indicating the range. KruskalWallis test for a trend showed $\mathrm{p}$ value $=0.01$.

doi:10.1371/journal.pone.0132780.g007

hydrophilic face consistently oriented towards the aqueous exterior, and its hydrophobic face either packed on to the hydrophobic face of another helical region of the protein (in the lipidfree form) or on to the lipid surface (in both HDL forms). Importantly, since peptides corresponding to this region do not show enhanced neutralization of the anti-ApoA-I signal of polyclonal IgG from an immunized animal (Fig 1c), it is unlikely that the C-terminal alpha-helix of ApoA-I is favored in the autoantibody responses in humans because it contains intrinsically immunodominant epitopes. While the mechanisms by which anti-ApoA-I antibodies arise remain elusive, the focused nature of the anti-ApoA-I autoantibody response (this study and [28]) could be an indication for the involvement of pathogen molecular mimicry i.e. generation of antibodies against a pathogen molecule that is structurally similar to the region of ApoA-I corresponding to Peptide F. Pathogen molecular mimicry has been put forward as an explanation for the generation of autoantibodies related to other pathologies [29-31], and could explain how anti-ApoA-I IgG can arise in subjects who do not show any signs of genuine loss of self-tolerance [14-17].

\section{Use of ApoA-I-mimetic peptides based on the C-terminal alpha-helix epitope as tools for prognosis and diagnosis of atherosclerosis and CVD}

Detecting circulating levels of anti-ApoA-I autoantibodies in patients is a promising strategy for developing new assays for risk stratification in atherosclerosis and CVD [12, 14-18, 32], and the evidence for bias in the anti-ApoA-I autoantibody response towards the C-terminal helix of the protein provides a rationale for developing peptide-based prognostic and diagnostic tests based on this region. Indeed using an optimized mimetic peptide to diagnose the occurrence of an acute ischemic coronary event (non-ST segment elevation myocardial 
infarction and unstable angina) on a cohort of acute chest pain patients, we were able to approach the diagnostic accuracy obtainable using intact endogenous ApoA-I. Further optimization of the peptide antigen, together with optimization of its immobilization in the immunoassay, should enable improvements in diagnostic accuracy from this starting point.

\section{Use of ApoA-I-mimetic peptides based on the C-terminal alpha-helix epitope to block the pathogenic activity of anti-ApoA-I IgG}

There is increasing evidence to suggest that anti-ApoA-I autoantibodies play a direct role in the pathogenesis of atherosclerosis and CVD and as such should be considered as targets for therapeutic intervention [12, 14-18]. Here we have shown that peptides from the C-terminal region of ApoA-I strongly inhibit one of the pathogenesis-associated activities of anti-ApoA-I autoantibodies, release of proinflammatory cytokines from cultured macrophages (Figs 5, 6 and 7), with F3L1, the stapled version of Peptide F, showing clearly improved inhibitory potency (Fig 7). Hence we have shown that optimized ApoA-I-derived peptides can inhibit the anti-ApoA-I IgG-mediated inflammatory response in vitro, but whether this will translate into blockade of pro-atherogenic effects in vivo [15] remains to be demonstrated.

Notably, the almost complete inhibition achieved by F3L1 of goat anti-ApoA-I IgGmediated pathogenesis-associated activity suggests that antibodies directed towards the Cterminal alpha-helical region of ApoA-I are primarily responsible for the previously described proinflammatory effects mediated by anti-ApoA-I $\operatorname{IgG}[12,14-18]$. This observation is of relevance to the elucidation of the structural specificity of pathogenesis-associated anti-ApoA-I antibodies [19].

Given the fact that F3L1 does not contain the LCAT activation site (residues 165-206 of ApoA-I) [8] and that immunoreactivity to peptides covering this regions were devoid of significant diagnostic accuracy, it is likely that antibodies to F3L1 do not interfere with cholesterol efflux. These results are in line with unpublished results from our group showing that sera from patients containing high levels of anti-apoA-I IgG do not interfere with cholesterol efflux in vitro.

Finally, with respect to the disputed clinical efficacy of ApoA-I mimetic peptides administered to unselected high-risk patients [33-35], our observations support the hypothesis that restricting the administration of such compounds to patients with high levels of anti-apoA-I IgG could improve the efficiency and the individualized nature of ApoA-I mimetic peptidebased therapy. Nevertheless, given the fact that the extrapolation of in vitro data to human physiopathology in the field of HDL and ApoA-I has been known to be particularly difficult [8], this appealing hypothesis requires to be demonstrated.

\section{Perspectives for further optimization of ApoA-I-mimetic peptides}

We have shown that the capacity of ApoA-I-mimetic peptides to bind to (Fig 3) and neutralize (Fig 7) the effects of anti-ApoA-I autoantibodies can be improved through the use of a helix staple' to enhance alpha-helical content, and it is likely that further optimization will be possible from this starting point. Firstly because some of the epitopes recognized by the antiApoA-I autoantibodies may have been masked by the structure of the lactam staple used in F3L1, and secondly because further constraint into the native alpha-helical conformation is likely possible. Indeed, several other helix-stapling approaches have been described $[24,27,36]$ in addition to lactam bridge formation; changing the nature, position and number of helix staples should enable identification of the optimal combination to minimize epitope masking and maximize conformational constraint. 


\section{Scope for future work to address the limitations of this study}

One limitation of this study is the small study sample size of our acute chest pain cohort. In future work it will be important: (i) to replicate and validate these preliminary results at larger multicenter scale, and (ii) to determine whether the diagnostic accuracy of immunoreactivity to F3L1 or other optimized peptides is equivalent to the one obtained with endogenous ApoA-I, and whether it could provide incremental diagnostic information over high-sensitive troponin assays. A second important limitation is that STEMI patients were excluded from this study. The rationale for excluding these patients relates to the fact that biomarkers in general are only of marginal value in the early management of STEMI, whereas they represent the cornerstone of MI diagnosis in NSTEMI settings [22]. Since NSTEMI patients are known to be older, to have a higher number of co-morbidities, and to be at greater risk of developing CV complications after acute MI than STEMI patients [37], further large-scale studies that include both STEMI and NSTEMI patients will be required in order to completely define the prognostic value of those autoantibodies for cardiovascular disease. Such studies would also allow the value of using levels F3L1-reactive antibodies for risk stratification in primary prevention settings to be assessed.

\section{Conclusion}

In this study we have provided evidence that the anti-ApoA-I autoantibody response in humans is biased towards the C-terminal alpha-helical region of the protein. In addition to providing insights into the mechanism by which anti-ApoA-I autoantibodies are elicited in subjects without autoimmune disease, this observation provides a rationale for the development of new ApoA-I mimetic peptides with potential use in both diagnosis and targeted therapy of atherosclerosis and CVD.

\section{Acknowledgments}

We thank Julien Virzi (Geneva University Hospital) for his skillful technical assistance. We gratefully acknowledge support for this work from the Fondation Leenaards.

\section{Author Contributions}

Conceived and designed the experiments: NV SP OH. Performed the experiments: HG SP FC PC PCT TM NS. Analyzed the data: SP NV OH. Contributed reagents/materials/analysis tools: PC PCT HG. Wrote the paper: NV OH SP FM.

\section{References}

1. Eyre H, Kahn R, Robertson RM, Clark NG, Doyle C, Hong Y, et al. Preventing cancer, cardiovascular disease, and diabetes: a common agenda for the American Cancer Society, the American Diabetes Association, and the American Heart Association. Circulation. 2004; 109(25):3244-55. Epub 2004/06/ 17. doi: 10.1161/01.CIR.0000133321.00456.00 PMID: 15198946.

2. Naghavi M, Falk E, Hecht HS, Jamieson MJ, Kaul S, Berman D, et al. From vulnerable plaque to vulnerable patient-Part III: Executive summary of the Screening for Heart Attack Prevention and Education (SHAPE) Task Force report. Am J Cardiol. 2006; 98(2A):2H-15H. Epub 2006/07/18. doi: 10.1016/j. amjcard.2006.03.002 PMID: 16843744.

3. Libby P, Ridker PM, Hansson GK. Progress and challenges in translating the biology of atherosclerosis. Nature. 2011; 473(7347):317-25. Epub 2011/05/20. doi: 10.1038/nature10146 PMID: 21593864.

4. Roux-Lombard P, Pagano S, Montecucco F, Satta N, Vuilleumier N. Auto-antibodies as emergent prognostic markers and possible mediators of ischemic cardiovascular diseases. Clin Rev Allergy Immunol. 2013; 44(1):84-97. Epub 2010/12/29. doi: 10.1007/s12016-010-8233-z PMID: 21188647.

5. Ajees AA, Anantharamaiah GM, Mishra VK, Hussain MM, Murthy HMK. Crystal structure of human apolipoprotein A-I: insights into its protective effect against cardiovascular diseases. Proceedings of 
the National Academy of Sciences of the United States of America. 2006; 103(7):2126-31. doi: 10. 1073/pnas.0506877103 PMID: 16452169

6. Davidson WS, Thompson TB. The Structure of Apolipoprotein A-I in High Density Lipoproteins. Journal of Biological Chemistry. 2007; 282(31):22249-53. doi: 10.1074/jbc.R700014200 PMID: 17526499

7. Navab M, Reddy ST, Van Lenten BJ, Fogelman AM. HDL and cardiovascular disease: atherogenic and atheroprotective mechanisms. Nat Rev Cardiol. 2011; 8(4):222-32. Epub 2011/02/10. doi: 10.1038/ nrcardio.2010.222 PMID: 21304474.

8. Vuilleumier N, Dayer JM, von Eckardstein A, Roux-Lombard P. Pro- or anti-inflammatory role of apolipoprotein A-1 in high-density lipoproteins? Swiss Med Wkly. 2013; 143:w13781. Epub 2013/06/07. doi: 10.4414/smw.2013.13781 PMID: 23740387.

9. Ames PR, Matsuura E, Batuca JR, Ciampa A, Lopez LL, Ferrara F, et al. High-density lipoprotein inversely relates to its specific autoantibody favoring oxidation in thrombotic primary antiphospholipid syndrome. Lupus. 2010; 19(6):711-6. Epub 2010/01/13. doi: 10.1177/0961203309357765 PMID: 20064910.

10. Batuca JR, Ames PR, Isenberg DA, Alves JD. Antibodies toward high-density lipoprotein components inhibit paraoxonase activity in patients with systemic lupus erythematosus. Annals of the New York Academy of Sciences. 2007; 1108:137-46. Epub 2007/09/26. PMID: 17893980.

11. Dinu AR, Merrill JT, Shen C, Antonov IV, Myones BL, Lahita RG. Frequency of antibodies to the cholesterol transport protein apolipoprotein A1 in patients with SLE. Lupus. 1998; 7(5):355-60. Epub 1998/ 08/08. PMID: 9696140.

12. Vuilleumier N, Bas S, Pagano S, Montecucco F, Guerne P-A, Finckh A, et al. Anti-apolipoprotein A-1 IgG predicts major cardiovascular events in patients with rheumatoid arthritis. Arthritis and rheumatism. 2010; 62(9):2640-50. doi: 10.1002/art.27546 PMID: 20506304

13. Vuilleumier N, Bratt J, Alizadeh R, Jogestrand T, Hafström I, Frostegård J. Anti-apoA-1 IgG and oxidized LDL are raised in rheumatoid arthritis (RA): potential associations with cardiovascular disease and RA disease activity. Scandinavian journal of rheumatology. 2010; 39(6):447-53. doi: 10.3109/ 03009741003742755 PMID: 20604674

14. Keller PF, Pagano S, Roux-Lombard P, Sigaud P, Rutschmann OT, Mach F, et al. Autoantibodies against apolipoprotein A-1 and phosphorylcholine for diagnosis of non-ST-segment elevation myocardial infarction. J Intern Med. 2012; 271(5):451-62. Epub 2011/11/09. doi: 10.1111/j.1365-2796.2011. 02479.x PMID: 22061093.

15. Montecucco F, Vuilleumier N, Pagano S, Lenglet S, Bertolotto M, Braunersreuther V, et al. Anti-Apolipoprotein A-1 auto-antibodies are active mediators of atherosclerotic plaque vulnerability. European heart journal. 2011; 32(4):412-21. doi: 10.1093/eurheartj/ehq521 PMID: 21224292

16. Vuilleumier N, Montecucco F, Spinella G, Pagano S, Bertolotto M, Pane B, et al. Serum levels of antiapolipoprotein A-1 auto-antibodies and myeloperoxidase as predictors of major adverse cardiovascular events after carotid endarterectomy. Thromb Haemost. 2013; 109(4). Epub 2013/02/01. doi: 10.1160/ TH12-10-0714 PMID: 23364307.

17. Vuilleumier N, Rossier MF, Pagano S, Python M, Charbonney E, Nkoulou R, et al. Anti-apolipoprotein A-1 IgG as an independent cardiovascular prognostic marker affecting basal heart rate in myocardial infarction. European heart journal. 2010; 31(7):815-23. doi: 10.1093/eurheartj/ehq055 PMID: 20176799

18. Finckh A, Courvoisier DS, Pagano S, Bas S, Chevallier-Ruggeri $P$, Hochstrasser D, et al. Evaluation of cardiovascular risk in patients with rheumatoid arthritis: do cardiovascular biomarkers offer added predictive ability over established clinical risk scores? Arthritis care \&amp; research. 2012;: 64(6):817-25. doi: 10.1002/acr.21631

19. Pagano S, Satta N, Werling D, Offord V, de Moerloose P, Charbonney E, et al. Anti-apolipoprotein A-1 IgG in patients with myocardial infarction promotes inflammation through TLR2/CD14 complex. J Intern Med. 2012; 272(4):344-57. Epub 2012/02/15. doi: 10.1111/j.1365-2796.2012.02530.x PMID: 22329401.

20. Rossier MF, Pagano S, Python M, Maturana AD, James RW, Mach F, et al. Antiapolipoprotein A-1 IgG chronotropic effects require nongenomic action of aldosterone on L-type calcium channels. Endocrinology. 2012; 153(3):1269-78. doi: 10.1210/en.2011-1835 PMID: 22253414

21. Srivastava R, Yu S, Parks BW, Black LL, Kabarowski JH. Autoimmune-mediated reduction of highdensity lipoprotein-cholesterol and paraoxonase 1 activity in systemic lupus erythematosus-prone gld mice. Arthritis and rheumatism. 2011; 63(1):201-11. Epub 2010/10/01. doi: 10.1002/art.27764 PMID: 20882670; PubMed Central PMCID: PMC3032585.

22. Thygesen K, Alpert JS, Jaffe AS, Simoons ML, Chaitman BR, White HD, et al. Third universal definition of myocardial infarction. Eur Heart J. 2012; 33(20):2551-67. doi: 10.1093/eurheartj/ehs184 PMID: 22922414. 
23. Kates SA, Sole NA, Johnson CR, Hudson D, Barany G, Albericio F. A novel, convenient, threedimensional orthogonal strategy for solid phase synthesis of cyclic peptides. Tetrahedron letters. 1993; (34: ):1549-52.

24. Taylor JW. The synthesis and study of side-chain lactam-bridged peptides. Biopolymers. 2002; 66(1): 49-75. Epub 2002/09/14. doi: 10.1002/bip.10203 PMID: 12228920.

25. Antman EM, Cohen M, Bernink PJ, McCabe CH, Horacek T, Papuchis $\mathrm{G}$, et al. The TIMI risk score for unstable angina/non-ST elevation MI: A method for prognostication and therapeutic decision making. JAMA. 2000; 284(7):835-42. Epub 2000/08/11. PMID: 10938172.

26. DeLong ER, DeLong DM, Clarke-Pearson DL. Comparing the areas under two or more correlated receiver operating characteristic curves: a nonparametric approach. Biometrics. 1988; 44(3):837-45. PMID: 3203132.

27. Patgiri A, Menzenski MZ, Mahon AB, Arora PS. Solid-phase synthesis of short alpha-helices stabilized by the hydrogen bond surrogate approach. Nat Protoc. 2010; 5(11):1857-65. Epub 2010/10/30. doi: 10.1038/nprot.2010.146 PMID: 21030960.

28. Teixeira PC, Ducret A, Ferber P, Gaertner H, Hartley O, Pagano S, et al. Definition of human apolipoprotein a-I epitopes recognized by autoantibodies present in patients with cardiovascular diseases. $J$ Biol Chem. 2014; 289(41):28249-59. Epub 2014/08/30. doi: 10.1074/jbc.M114.589002 PMID: 25170076; PubMed Central PMCID: PMC4192480.

29. Cunningham MW. Streptococcus and rheumatic fever. Curr Opin Rheumatol. 2012; 24(4):408-16 Epub 2012/05/24. doi: 10.1097/BOR.0b013e32835461d3 PMID: 22617826; PubMed Central PMCID: PMC3645882.

30. Krauel K, Potschke C, Weber C, Kessler W, Furll B, Ittermann T, et al. Platelet factor 4 binds to bacteria, [corrected] inducing antibodies cross-reacting with the major antigen in heparin-induced thrombocytopenia. Blood. 2011; 117(4):1370-8. Epub 2010/10/21. doi: 10.1182/blood-2010-08-301424 PMID: 20959601.

31. Yuki N. Infectious origins of, and molecular mimicry in, Guillain-Barre and Fisher syndromes. The Lancet infectious diseases. 2001; 1(1):29-37. Epub 2002/03/02. doi: 10.1016/S1473-3099(01)00019-6 PMID: 11871407.

32. Wick PA, Mombelli A, Pagano S, Moren X, Giannopoulou C, Mach F, et al. Anti-apolipoprotein A-1 autoantibodies as biomarker for atherosclerosis burden in patients with periodontitis. J Periodontal Res. 2013; 48(3):350-6. Epub 2012/10/12. doi: 10.1111/jre.12014 PMID: 23050768.

33. Watson CE, Weissbach N, Kjems L, Ayalasomayajula S, Zhang Y, Chang I, et al. Treatment of patients with cardiovascular disease with L-4F, an apo-A1 mimetic, did not improve select biomarkers of HDL function. J Lipid Res. 2011; 52(2):361-73. Epub 2010/11/12. doi: 10.1194/jlr.M011098 PMID: 21068008; PubMed Central PMCID: PMC3023557.

34. Hafiane A, Kellett S, Genest J. Treatment options for low high-density lipoproteins. Curr Opin Endocrinol Diabetes Obes. 2014; 21(2):134-9. Epub 2014/02/19. doi: 10.1097/MED.0000000000000049 PMID: 24535232.

35. Bloedon LT, Dunbar R, Duffy D, Pinell-Salles P, Norris R, DeGroot BJ, et al. Safety, pharmacokinetics, and pharmacodynamics of oral apoA-I mimetic peptide D-4F in high-risk cardiovascular patients. J Lipid Res. 2008; 49(6):1344-52. Epub 2008/03/08. doi: 10.1194/jIr.P800003-JLR200 PMID: 18323573; PubMed Central PMCID: PMC2386905.

36. Henchey LK, Jochim AL, Arora PS. Contemporary strategies for the stabilization of peptides in the alpha-helical conformation. Current opinion in chemical biology. 2008; 12(6):692-7. Epub 2008/09/17. doi: 10.1016/j.cbpa.2008.08.019 PMID: 18793750; PubMed Central PMCID: PMC2650020.

37. McManus DD, Gore J, Yarzebski J, Spencer F, Lessard D, Goldberg RJ. Recent trends in the incidence, treatment, and outcomes of patients with STEMI and NSTEMI. Am J Med. 2011; 124(1):40-7. doi: 10.1016/j.amjmed.2010.07.023 PMID: 21187184; PubMed Central PMCID: PMC3011975. 